\title{
Design of trainer kit as a fault-finding based on electricity and electronics learning media
}

\author{
Muhammad Anwar * 1, Mochamad Bruri Triyono ${ }^{2}$, Ta'ali Ta'ali ${ }^{1}$, Hendra Hidayat ${ }^{1}$, Veva \\ Nellone Syahputeri ${ }^{1}$ \\ ${ }^{1}$ Universitas Negeri Padang. \\ ${ }^{2}$ Universitas Negeri Yogyakarta. \\ * Corresponding Author. Email: muh anwar@ft.unp.ac.id
}

\section{ARTICLE INFO}

\section{Article History}

Received:

8 September 2021;

Revised:

27 September 2021,

Accepted:

28 October 2021;

Available online:

12 November 2021

Keywords

Fault finding;

Learning media;

Trainer kit

\begin{abstract}
According to the field of expertise, efforts to strengthen the competence of graduates continue to be pursued, especially through optimizing the learning process. Among these efforts is to use learning media that strengthen the competence of the field of study and about thinking skills. This study aims to produce a trainer kit as a medium for learning basic electricity and electronics based on fault-finding in Basic Electrical and Electronics subjects. The method used is the Richey and Klein Design and Development (D\&D) method which consists of three stages, including planning (design), production, and evaluation. Experts carried out the assessment of the feasibility of the trainer kit with an instrument in the form of a questionnaire. The results of this study indicate that the trainer kit has a good performance.
\end{abstract}

This is an open access article under the $\underline{\mathrm{CC}-\mathrm{BY}-\mathrm{SA}}$ license.

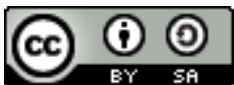

\begin{abstract}
How to cite:
Anwar, M., Triyono, M. B., Ta'ali, T., Hidayat, H., \& Syahputeri, V. N. (2021). Design of trainer kit as a fault-finding based on electricity and electronics learning media. Jurnal Pendidikan Vokasi, 11(2), 192-203. https://doi.org/10.21831/jpv.v11i2.43742
\end{abstract}

\section{INTRODUCTION}

The 21st century or the information or knowledge era has shifted the need for the world of work for the skill structure of the workforce where the role and position of brainpower are more dominant. In other words, good thinking skills from the workforce are more needed than those related to just hard skills. In line with Prosser's expression in the 16 principles of vocational education (work habits), individuals must be trained with thinking skills and work according to their job needs (Sudira, 2013). The professional competencies in electronics expertise are divided into two categories: general competencies including analytical reasoning, problem-solving, and technical competencies including analyzing, building, and evaluating electronic systems (The United States Office of Personnel Management, 2013). Thus, to be able to survive in the challenges of the 21 st century, hard skills and thinking skills such as problem-solving are needed (Griffin et al., 2012; Irianto, 2017; Wagner, 2008).

The above statement is in line with the competence of Vocational High School (VHS) graduates, namely having the ability to think logically, critically, creatively and, innovatively in making decisions, as well as the ability to analyze and solve complex problems (Andrian \& Rusman, 2019; A. Kurniawan et al., 2019). In addition, the aim of VHS is also to produce graduates and skilled workers in their fields (Nuri \& Rusilowati, 2018; Rizaldi et al., 2021; Wening, 2017). However, in 
reality, the demands for competence at the VHS level are not compatible with the implementation and learning in VHS. Based on BPS data for the last three years, the Open Unemployment Rate (TPT) of SMK graduates ranks the highest (Figure 1).

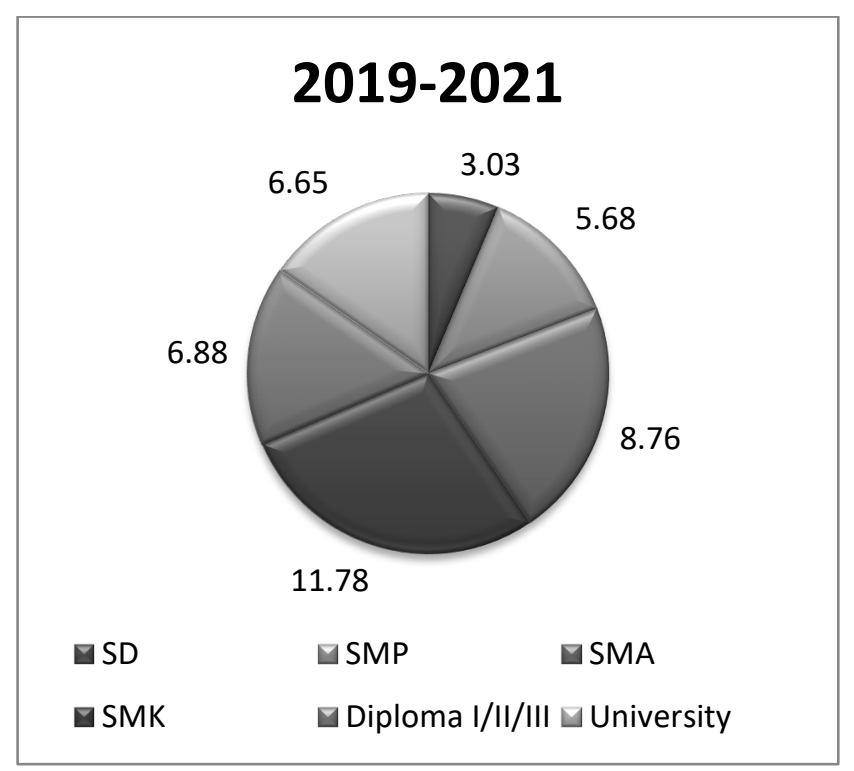

Figure 1. Open Unemployment Rate (TPT) by Highest Education Graduated (percent), 2019 2021 (Central Bureau of Statistics of the Republic of Indonesia, 2011)

A shift influences the factor of the high unemployment rate for vocational school graduates in workforce competence in the world of work and the influence of learning aspects for the achievement of graduate competencies, including learning models and media (Hamid et al., 2017; Setyo, 2016; Tafonao, 2018). The basic subjects of electricity and electronics in vocational high schools are principal and basic subjects because they are provisions for advanced lessons and basic work in the industry. However, the findings in the field are not many students who master and understand the basic material concepts of electricity and electronics. In addition, monotonous learning because it is teacher-centered, laboratory equipment and media sources that are less supportive affect student learning outcomes (Hamid et al., 2017; Hapnita, 2018; B. Kurniawan et al., 2017).

The average score evidences the low quality of learning for the last three years in SMK is less than 65\%, which indicates ineffective learning (Setyosari, 2014; Yayuk \& Sugiyono, 2019). So effective, interactive, and collaborative learning is needed to improve the achievement of skill competencies, especially thinking skills (problem-solving). One alternative is a trainer kit as a learning medium (Anshary \& Edidas, 2018; Rauner \& Maclean, 2008; Sukmadinata, 2008). The use of trainer kits can make it easier for students to understand learning material because it aims to concretize the abstract so that students' understanding and perceptions become better (Arsyad, 2010; Daryanto, 2016; Hariyanto et al., 2020; Nizar, 2016).

The design of trainer kits as alternative learning media has been widely developed, such as conveyor trainer kits for learning programmable logic control (Sukir et al., 2017) and development of electrical lighting installation trainer kits (Wahono \& Sukir, 2020). The design of the trainer kit by the researcher is the basic electrical and electronics trainer kit based on fault finding. Fault finding is an effort by students to solve problems independently and in groups through fault-finding, which consists of five stages, namely questioning interpretation, strategy determination, and implementation (fault \& signal tracking), diagnosis, and presentation (Anwar, 2016; Keddie, 2008; Pain, 1996).

In the above fault-finding stages, it can be explained that fault-finding is a form of a problemsolving approach. Students will be brought to understand the material through the process of interpreting the problem, using the knowledge base to generate several alternative answers or solutions and choosing the best solution logically. The problem in question is the core material and competencies that must be achieved, formulated in the form of questions or cases, then understood 
and resolved by students through teacher facilitation. This process theoretically will be able to train and improve students' thinking skills, especially related to problem-solving skills. For the effectiveness of practical learning, media supporting the implementation of the method is an absolute requirement so that learning objectives can be achieved (Anwar, 2016; Rauner \& Maclean, 2008; Sukmadinata, 2008).

\section{RESEARCH METHOD}

This study used the Richey and Klein method. The Richey and Klein method is a Design and Development model that systematically examines how to design a product, develop or produce a design, and evaluate product performance, aiming to obtain empirical data used as the basis for making products, tools, etc., models for learning or non-learning. This method consists of three stages: planning (design), production, and evaluation, commonly called the PPE model (Narulita et al., 2021; Rustandi et al., 2020; Sugiyono, 2017). In detail, the research phase using the Richey and Klein Model can be seen in Figure 2.

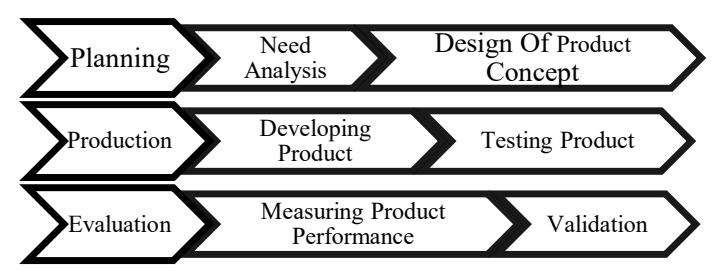

\section{Figure 2. The Design Phase of The Basic Electrical and Electronics Trainer Kit}

The steps of this research are: 1.) Analyzing and conducting needs analysis in VHS based on the basic competencies of basic electrical and electronic subjects; 2.) Designing a basic electrical and electronic trainer kit based on fault-finding; 3.) Developing a basic electrical and electronics trainer kit based on fault-finding, and the results are validated and reviewed by experts; 4.) The implementation of the basic electrical and electronic test trainer kit based on fault finding and the results are evaluated; and 5.) The validation of the basic electrical and electronic trainer kit product was carried out by two experts. The technique of collecting data is through tests with instruments in the form of questionnaires and examinations. The reliability of the assessment instrument in the form of a questionnaire was determined by calculating the reliability coefficient using the Cronbach Alpha formula

\section{RESULT AND DISCUSSION}

The first step of this research is to conduct a needs analysis on the basic subjects of electricity and electronics. The result of needs analysis that stands out is the lack of laboratory equipment to support practical activities. Based on the basic competencies of basic electrical and electronics subjects, the need in designing a trainer kit is measuring equipment including voltmeters and galvanometers as well as electronic systems, namely DC power supply, audio amplifier, op-amp comparator, and IC LM555 timer.

The second step of this research is to design a basic electrical and electronics trainer kit based on fault finding. Based on the needs analysis of the basic competencies of DLE subjects, the trainer kit is designed with four electronic systems and measurement instruments. The fault-finding method in the design of the trainer kit is implemented as a simulation switch. The simulation switch serves to break the current in the circuit in each system. 
The third step of this research is to make a basic electrical and electronics trainer kit based on fault finding. The results of the trainer kit are present in Figure 3. The fourth step of this research is testing the basic electrical and electronic trainer kit based on fault finding. The results of the trainer kit test are present in Table 1.

The last step of this research is the validation of the trainer kit by the experts. Evaluation of the trainer kit product was carried out through a validation process involving two media experts. The results from media experts on the design, performance (technical), and the feasibility of fault-finding basic electrical and electronics trainer kits in learning (instructional) are present in Table 2. Suggestions given by experts are that the placement of measuring points should be reduced and the connection of lines considered.

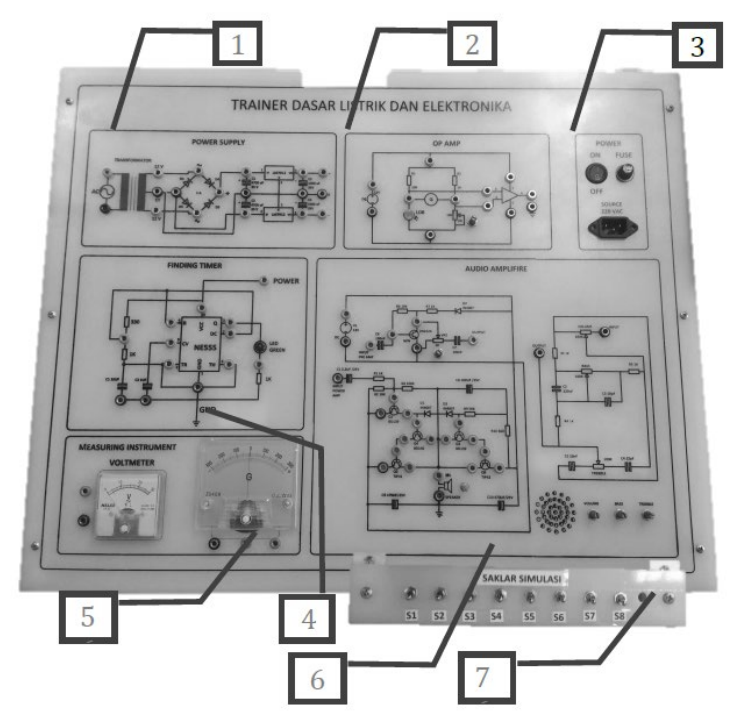

Description: 1.) DC power supply; 2.) Op-amp comparator; 3.) Power; 4.) Audio amplifier; 5.) Measurement instrument; 6.) Astable timer; 7.) Simulation switch.

\section{Figure 3. Trainer Kit Design}

Table 1. Measurement of Basic Electrical and Electronics Trainer Kit

\begin{tabular}{lccc}
\hline \multicolumn{1}{c}{ Moeasuring Point } & Ideal Value & Measured Value & Description \\
\hline A. DC Power Supply & & & \\
1. Stepdown Transformer Primary Terminal & $220 V_{A C}$ & $230 V_{A C}$ & Valid \\
2. Stepdown Transformer Secondary Terminal & $12 V_{A C}$ & $13 V_{A C}$ & Valid \\
3. Voltage Regulator LM7812 Output & $+12 V_{D C}$ & $12 V_{D C}$ & Valid \\
4. Voltage Regulator LM7912 Output & $-12 V_{D C}$ & $12 V_{D C}$ & Valid \\
B. Audio Amplifier & & & \\
1. Pre Amp Gain & \pm 2 to $3 \mathrm{x}$ & $3 \mathrm{x}$ & Valid \\
2. Power Amp Gain & \pm 11 to $422 \mathrm{x}$ & $21 \mathrm{x}$ & Valid \\
C. Op-Amp. Comparator & & & \\
1. LM741 Input Voltage & $\pm 15 V_{D C}$ & $12 V_{D C}$ & Valid \\
2. Wheatstone Bridge & 0 & 0 & Valid \\
D. Astable Timer IC LM55 & & & \\
1. Source Voltage & $5-18 V_{D C}$ & $12 V_{D C}$ & Valid \\
2. Trigger Voltage & VCC/3 & $6 V_{D C}$ & Valid \\
3. Threshold Voltage & $2 / 3 \mathrm{VCC}$ & $6 V_{D C}$ & Valid \\
\hline
\end{tabular}


Table 2. Media Expert Validation Results on the Suitability of the DLE Trainer Kit

\begin{tabular}{|c|c|c|c|}
\hline \multirow{2}{*}{ No. } & \multirow{2}{*}{ Aspect } & \multicolumn{2}{|c|}{ Media Expert } \\
\hline & & Value & Category \\
\hline 1. & Design & 0.94 & Very Worthy \\
\hline 2. & Technical & 0.97 & Very Worthy \\
\hline 3. & Instructional & 0.85 & Very Worthy \\
\hline & Overall aspect & 0.92 & Very Worthy \\
\hline
\end{tabular}

To determine the consistency of the results of the study, namely the consistency of media assessment instruments, the Cronbach Alpha reliability test was carried out. The reliability of the trainer kit assessment instrument was 0.774 for the validation of the assessment format and 0.750 for the trainer kit assessment. So based on the results of the reliability test, it can be concluded that the media assessment instrument has a high level of reliability with a Cronbach Alpha value of 0.70 0.90 (Budiastuti \& Bandur, 2018; Sa'adah, 2021).

The trainer kit as a fault-finding-based learning media was developed using the PPE development model (planning, production, evaluation). This development process starts from the planning or planning stage to plan a trainer kit by setting and defining the requirements and needs in the learning process. This stage is carried out by carrying out field observations, namely in the vocational high school in the field of electronic engineering expertise, then the results of the observations are used as a reference in designing the trainer kit design. Field observation activities are carried out by conducting analysis, namely curriculum analysis, basic competency analysis, subject syllabus analysis, and field analysis. Analysis of the learning components (curriculum, basic competencies, and syllabus) aims to assist direction in making learning media by the objectives of achieving competence. At the same time, the field analysis aims to find out how the factual conditions of the learning process take place. The above analyzes are grouped into one form as a needs analysis.

The results of the needs analysis that stand out are in the learning aspect, namely the lack of laboratory equipment to support practicum activities which have led to a lack of skill competency achievement for the last three years, as evidenced by an average score of less than $65 \%$. So we need an effective learning media for practical activities, namely a trainer kit. To be able to design a trainer kit that is relevant to learning, a trainer kit needs analysis is carried out based on the basic competencies of Basic Electrical and Electronics (DLE) subjects. However, learning refers to the media used and the learning model in maximizing media use (Hamid et al., 2017; Setyo, 2016; Tafonao, 2018).

Fault-finding is an effort of independent-group learners to answer questions and solve problems through error diagnosis. This method consists of several main steps which are described as follows: 1.) Questioning, carried out by explaining the circuit diagram and then accompanied by questions/cases/problems by the teacher with reference to the learning objectives; 2.) Interpretation of the problem, carried out by means of in-depth understanding accompanied by the introduction of the type of system by students, then unraveling the problem under the guidance of the teacher; 3.) Determination and implementation of strategies, carried out by selecting a strategy for tracking and localizing errors (fault \& signal tracking) by students under the guidance of the teacher; 4.) Diagno-sis, carried out by means of testing, description and recording of error detection by students, as an answer to the case/problem posed, under the direction of the teacher; and 5.) Presentation, carried out by displaying the results of the error diagnosis accompanied by logical and systematic arguments, both theoretical and practical by students under the direction of the teacher (Anwar, 2016).

The last step of the planning stage is the design of the trainer kit. The design is intended to visually describe the shape of the trainer kit that will be made. The components, circuits, and systems that will be designed in the trainer kit are obtained based on a needs analysis of the basic competencies of related subjects. Furthermore, it is formulated in such a way as to implement faultfinding in the trainer kit so that it is following the achievement of learning objectives and the competencies set. 
The next stage is the production stage. This stage aims to realize the trainer kit design into one form of a complete trainer kit construction. This stage is divided into two steps: developing a trainer kit and testing a trainer kit. The development of the trainer kit is intended to realize the design of the four electronic systems used, namely DC power supply, audio amplifier, op-amp comparator, astable timer, and measurement instruments into the form of construction as shown in Figure 3. Then the construction of the trainer kit will go through a measurement test and simulations to determine the stability of the system made.

Based on the production stage, it was determined that the Trainer kit is made of acrylic and wood with a length of $66 \mathrm{~cm}$, a width of $53 \mathrm{~cm}$, a front height of $8 \mathrm{~cm}$, and a back height of $15 \mathrm{~cm}$. The center of the trainer kit consists of an electronic system, including a DC power supply, audio amplifier, op-amp comparator, astable timer, voltmeter, and galvanometer. Meanwhile, eight simulation switches are placed on the side of the trainer kit. The electrical power needed is 220 Volt $\mathrm{AC}$ which is then rectified through a power supply with $+12 \mathrm{Vdc}$ and $-12 \mathrm{Vdc}$ outputs. Other supporting components of the trainer kit are jumper connectors and other supporting electronic devices.

Based on the results in Table 1. it can be seen that the performance of the trainer kit follows its design. It is characterized by the accuracy of the measuring value at the measuring point of the circuit against the ideal value of the circuit itself. Measurements are made using measuring instruments such as a multimeter and an oscilloscope. Not only referring to measurements, but the trainer kit test is also based on the simulation form.

The form of fault-finding-based trainer kit simulation is described as follows. Students will be brought to understand the electronic system contained in the trainer kit, namely an understanding of the DC power supply system, audio amplifier, op-amp comparator, and astable timer where the four systems have been declared stable through the measurements in Table 1. But in reality, the simulation results when associated with the simulation switch or, in other words, the simulation switch is active. The results will be different from what has been described. This is a process of understanding the material by students through problem interpretation.

The problem in question is the core material and competencies that must be achieved, formulated in the form of questions or cases, then understood and resolved by students through teacher facilitation. In other words, students are required to understand in detail the workings of the implemented electronic system and be able to solve problems that may occur in the system using a knowledge base to generate several alternative answers/solutions and choose the best solution logically.

The first simulation form is a DC power supply system which consists of a transformer circuit block, rectifier, filter, and voltage regulator with different functions. When the system is activated, it will produce an output voltage that matches the installed voltage regulator (Electronics Tutorials, n.d.-a; Tooley \& Tooley, 2002). When viewed with an oscilloscope, the waveform of the rectifier output does not show the waveform that should be due to the continuous flow of current. However, if the simulation switch is activated, it will produce a constant output voltage, but the output waveform of each block starting from the rectifier becomes visible. Of course, this happened for a logical reason.

The second form of simulation is an audio amplifier system consisting of a pre-amplifier circuit block, tone control, and power amplifier with different functions. When activated, the audio amplifier will amplify the frequency up to 422 times according to the input frequency (Boylestad \& Nashelsky, 1996; Cathey, 2002; Tooley \& Tooley, 2002). The audio amplifier system has three simulated switches on the pre-amplifier and power amplifier, which will disconnect one of the lines in the circuit when activated. If one of the switches is activated, then the gain result will be affected. For example, the simulation switch on the power amplifier is activated, then the gain becomes smaller. Why is that? Because there is one component in the circuit that loses its function.

The third form of simulation is an op-amp comparator which consists of an op-amp circuit block and a Wheatstone bridge. An Op-Amp comparator circuit compares the incoming signal voltage at the two input terminals. One of the terminals is given a constant voltage as a reference voltage, while the other terminal serves as an external signal input from another device, such as a Wheatstone bridge. The Wheatstone bridge circuit consists of 4 resistances, namely two fixed- 
resistance and two variable resistance, which are arranged in series, and at two diagonal points, a voltage source is provided.

When the value of R1.R3 = R2.R4, then the value of the current on both sides is the same, so they cancel each other out. This results in the value of the current on the galvanometer being zero or in a state of equilibrium so that the voltage on both sides is the same. Meanwhile, when R1.R3 $\neq$ R2.R4, the current value on both sides will be more negative or more positive. As a result, the voltage on both sides is not the same (Electronics Tutorials, n.d.-b; Syech et al., 2016). The voltage on the R1 R3 side becomes the input on the non-inverting leg of LM741, and the voltage on the R2 R4 side becomes the input on the LM741 inverting leg.

The Op-Amp comparator compares the magnitude of the two input voltages and produces an output voltage based on that comparison. Where one voltage is used as a reference voltage (Vref) and the other voltage as an input voltage (Vin), if the input voltage (Vin) is greater than the reference voltage (Vref), then the output voltage (Vout) approaches the positive value of VCC, and vice versa when the voltage is Vin is less than Vref then the output voltage (Vout) is close to the negative value of VCC (Cathey, 2002; Electronics Tutorials, n.d.-c). However, when the simulation switch is activated, the voltages Vin and Vref do not affect Vout. This indicates that one of the input voltages has not changed.

The fourth simulation form is an astable timer. The astable timer works based on the input voltage at the trigger terminal and threshold IC LM555. When the threshold voltage reaches $2 / 3 \mathrm{Vcc}$, the timer output is in a "low" condition, whereas when the trigger voltage reaches $1 / 3 \mathrm{Vcc}$, the timer output is in a "high" condition (Electronics Tutorials, n.d.-a; Tooley \& Tooley, 2002). However, if the simulation switch is activated, the IC LM555 output becomes "high". This indicates that the threshold voltage does not reach $2 / 3 \mathrm{Vcc}$ when the astable timer simulation switch is activated. Thus students are guided to develop reasoning thinking to get answers to the problems posed.

Benjamin S Bloom introduced the taxonomy of thinking (bloom taxonomy) into six categories: knowledge, understanding, application, analysis, synthesis, and evaluation (Sani, 2016). Then revised by Anderson and Krathwohl into six similar categories, namely remembering, understanding, applying, analyzing, evaluating, and creating (Sani, 2016). The level of analysis or analysis means solving problems into main parts through a systematic examination of facts or information. Thus, it can be said that the trainer kit simulation form based on fault-finding is fundamentally based on Bloom's taxonomy to improve students' thinking skills logically, systemic, complex, creative, critical, and evaluative as well as problem-solving skills.

To be able to achieve problem-solving skills, media are needed that can build content or materials to be arranged logically and systematically. Media also describes objects in content in a symbolic and tangible form. And learning media can help students get the information they need and build knowledge or fulfill curiosity without dependence on the teacher as a facilitator only (Anwar, 2016). Thus it can be stated that learning media is an intermediary that makes the material being studied interesting and helps students learn, think, and understand it. One form of this media is a fault-finding basic electrical and electronics trainer kit.

Referring to the simulation form that has been described, it will improve the student's learning experience, especially in the cognitive, affective, and psychomotor aspects (Anshary \& Edidas, 2018; Anwar, 2016). This learning experience will support the cone of experience theory that the more concrete the media used, the more real the experience achieved by students and can quickly master concepts. Meanwhile, the learning experience through abstract media makes it difficult for students to understand conceptual knowledge (Arsyad, 2010; Daryanto, 2016; Rauner \& Maclean, 2008).

In line with what was stated by Arsyad (2010) regarding the practical benefits of using learning media, learning media can clarify the presentation of messages and information to launch and improve learning processes and outcomes. Not only that, learning media can provide students with a common experience and overcome the limitations of the senses, space, and time. So that the role of learning media can improve learning achievement and provide a more concrete learning experience (Arsyad, 2010).

The last stage of the PPE development model is evaluation. The evaluation stage is a testing activity, assessing how high the product has met the predetermined specifications, including the 
achievement of the trainer kit as a learning medium. This stage is divided into two steps, namely, measuring the performance of the trainer kit and validation of the trainer kit by experts. The measurement of the performance of the trainer kit is intended to determine the feasibility of the stability of the performance of the trainer kit. Furthermore, the validation of the trainer kit was carried out by two media experts.

Based on the validation carried out by media experts on the basic electrical and electronics trainer kit based on fault finding, the score was 0,92, which was included in the very feasible category. Furthermore, the results of media expert validation on the performance of fault-finding basic electrical and electronics trainer kits got a value of 0,97 , which was included in the worth it category. In addition, the results of media expert validation on the feasibility of fault-finding basic electrical and electronics-based trainer kits as learning media got a value of 0,85 , which is included in the worth it category. So it can be said that the basic electrical and electronics trainer kit based on fault finding can be used as a learning medium.

The aspects assessed in the trainer kit validation are design, technical, and instructional aspects. The design aspects were assessed from the neatness of the layout, the accuracy of the measuring points, the clarity of symbols and component descriptions, the ease of access to the simulation switch, and the user's interest in the trainer kit. An untidy layout will have an impact on the attractiveness of the trainer kit to the user. Furthermore, the accuracy of the measuring point is intended to facilitate the user in determining the measuring point to be measured or, in other words, not to confuse the user in the measurement process. Component symbols and clear component descriptions can help users understand the working principle of the system's circuit. The simulation switch is a component that supports the application of the fault-finding method on the trainer kit,

The technical quality aspect is generally related to the appearance and performance of learning media. This aspect assesses that the learning media can be used easily by users, is easy to operate, and has good performance. This learning media can be used to assist in understanding the material being studied. Thus, the technical aspects (performance) are assessed based on the stability of the system work, the ease of operating the system, and the level of safety of the trainer kit (Kustandi \& Sutjipto, 2011). An unstable system will reduce the effectiveness of the learning media and affect the results of user measurements and observations of the circuit in the system, so the stability of the system's work is the main thing that needs to be considered before using a trainer kit as a learning medium. The second thing that needs to be considered during the operation of the trainer kit is the safety level of the trainer kit, considering that the trainer kit uses a direct current (AC) of 220 Volts from the PLN grid. Furthermore, the trainer kit as a learning media that aims to facilitate and equalize students' understanding in an abstract context becomes more concrete, of course in operation, it must be simple or easy so that students are not confused in the learning process (Arsyad, 2010; Daryanto, 2016).

The learning aspect is generally related to the role of the learning media. This aspect assesses the usefulness of learning media in helping to understand the material and increasing motivation. Thus the instructional or learning aspect is assessed based on the achievement of learning objectives, facilitating the learning process, representing basic competencies, growing student motivation, and stimulating students' thinking levels in learning using a fault finding-based trainer kit as a learning medium (Kustandi \& Sutjipto, 2011). This assessment is in line with the functions and benefits of learning media. The function of learning media is to motivate students to learn, present information, and stimulate students' minds and skills. Student skills are assessed based on aspects that refer to the competence of the field of expertise so that the basic learning media must also represent the basic competencies of the area of expertise. The benefits of learning media are increasing learning motivation and clarifying the presentation of information so that it can improve learning achievement, provide a more concrete learning experience and increase student activity in learning (Arsyad, 2010; Daryanto, 2016).

The validity of the learning media is in line with the evaluation form of the learning media. This evaluation aims to measure the extent to which the function and role of the media can be achieved or, in other words, assess the extent to which the effectiveness of the learning media (Rivai \& Sudjana, 2011). The purpose of the evaluation of learning media is to determine whether the learning media is effective, determine whether the media can be improved or improved, choose 
appropriate learning media to be used in the learning process, determine whether the material has been presented properly, find out whether the media helps with learning outcomes such as stated, and knowing the attitudes of students towards learning media (Arsyad, 2010; Daryanto, 2016).

The results of this study are in line with research conducted by Sukir et al. (2017), which proves that the conveyor trainer kit can effectively improve student learning experiences, especially in the cognitive, psychomotor, and affective aspects of PLC practicum learning in Indonesia. Another study conducted by Wahono and Sukir (2020) found that the electric lighting installation trainer kit developed simplifies the learning process and is useful in improving the learning experience. This study is also in line with the research conducted by Marpanaji et al. (2017), which showed that the PID controller trainer kit in the practice of learning control systems is feasible to use to improve problem-solving skills and understanding concepts. It is known that the objects and methods of applying the media in learning developed by the three types of research previously mentioned are different from this research. However, it can be related that the trainer kit as a learning media can influence learning effectively, interactively, and collaboratively.

\section{CONCLUSION}

This study shows that the fault-finding basic electrical and electronics trainer kit as a learning medium in basic electricity and electronics learning is worth it. It is characterized by a validity value of 0,85 and has a very good performance which is characterized by a validity value of 0,97 . This research has limited time and conditions. Therefore, further research is needed to implement faultfinding basic electrical and electronics trainer kits as learning media indirect learning activities for basic electrical and electronics subjects.

\section{REFERENCES}

Andrian, Y., \& Rusman, R. (2019). Implementasi pembelajaran abad 21 dalam kurikulum 2013. Jurnal Penelitian Ilmu Pendidikan, 12(1), 14-23. https://doi.org/10.21831/jpipfip.v12i1.20116

Anshary, I., \& Edidas, E. (2018). Pengembangan trainer mikrokontroler sebagai media pembelajaran dengan metode fault-finding. Voteteknika (Vocational Teknik Elektronika Dan Informatika), 6(2), 80-84. https://doi.org/10.24036/voteteknika.v6i2.102123

Anwar, M. (2016). Buku panduan model pembelajaran berpikir orde tinggi pada bidang keahlian elektronika. Universitas Negeri Yogyakarta.

Arsyad, A. (2010). Media pembelajaran. RajaGrafindo Persada.

Badan Pusat Statistik Republik Indonesia. (2011). Tingkat pengangguran terbuka lulusan SMK paling tinggi. Databoks.Katadata.Co.Id. https://databoks.katadata.co.id/datapublish/2021/11/06/tingkat-pengangguran-terbukalulusan-smk-paling-tinggi

Boylestad, R. L., \& Nashelsky, L. (1996). Electronic devices and circuit theory. Prentice Hall. http://www.rtna.ac.th/departments/elect/Data/EE306/Electronic Devices and Circuit Theory.pdf

Budiastuti, D., \& Bandur, A. (2018). Validitas dan reliabilitas penelitian: Dilengkapi analisis denan NVIVO, SPSS, dan AMOS. Penerbit Mitra Wacana Media. https://core.ac.uk/download/pdf/187725992.pdf

Cathey, J. J. (2002). Theory and problems of electronic devices and circuits (2nd ed.). McGraw-Hill. https://doi.org/0-07-139830-9

Daryanto, D. (2016). Media pembelajaran: Peranannya sangat penting dalam mencapai tujuan pembelajaran (2nd ed.). Gava Media. 
Electronics Tutorials. (n.d.-a). 555 circuits part 1. Electronics-Tutorials.Ws. Retrieved July 26, 2021, from https://www.electronics-tutorials.ws/waveforms/555-circuits-part-1.html

Electronics Tutorials. (n.d.-b). Full wave rectifier. Electronics-Tutorials.Ws. Retrieved July 26, 2021, from https://www.electronics-tutorials.ws/diode/diode_6.html

Electronics Tutorials. (n.d.-c). Wheatstone bridge. Electronics-Tutorials.Ws. Retrieved July 26, 2021, from https://www.electronics-tutorials.ws/blog/wheatstone-bridge.html

Griffin, P., McGaw, B., \& Care, E. (2012). Assessment and teaching of 21st century skills. Springer. https://doi.org/10.1007/978-94-007-2324-5

Hamid, M. A., Aribowo, D., \& Desmira, D. (2017). Development of learning modules of basic electronics-based problem solving in Vocational Secondary School. Jurnal Pendidikan Vokasi, 7(2), 149-157. https://doi.org/10.21831/jpv.v7i2.12986

Hapnita, W. (2018). Faktor internal dan eksternal yang dominan mempengaruhi hasil belajar menggambar dengan perangkat lunak siswa kelas XI teknik gambar bangunan SMK N 1 Padang tahun 2016/2017. CIVED (Journal of Civil Engineering and Vocational Education), 5(1), 2175-2182. https://doi.org/10.24036/cived.v5i1.9941

Hariyanto, H., Aribowo, D., \& Fatkhurrokhman, M. (2020). Pengembangan media pembelajaran trainer kit pengendali motor 3 phase pada mata pelajaran instalasi motor listrik di SMKN 4 Kota Serang. JURNAL PENDIDIKAN FISIKA DAN KEILMUAN (JPFK), 5(1), 1-7. https://doi.org/10.25273/jupiter.v5i1.6223

Irianto, D. (2017). Industry 4.0: The challanges of tomorrow. Seminar Nasional Teknik Industri (SNTI) Dan Seminar Nasional Terpadu Keilmuan Teknik Industri (SATELIT) 2017, 4-6. http://k8bksti.ub.ac.id/wp-content/uploads/2017/10/Keynote-Speaker-Dradjad-Irianto.pdf

Keddie, R. (2008). DG3J 35: Electronic fault finding. Scottish Qualifications Authority. https://studylib.net/doc/18794476/dg3j-35-electronic-fault-finding

Kurniawan, A., Mukhadis, A., \& Widiyanti, W. (2019). 21st century skills sebagai upaya pengembangan kapabilitas siswa SMK di Fourth Industrial Revolution Era. Jurnal Pendidikan: Teori, Penelitian, Dan Pengembangan, 4(7), 857-862. https://doi.org/10.17977/jptpp.v4i7.12614

Kurniawan, B., Wiharna, O., \& Permana, T. (2017). Studi analisis faktor-faktor yang mempengaruhi hasil belajar pada mata pelajaran teknik listrik dasar otomotif. Indonesian Journal of Science and Technology, 4(2), 156-162. https://doi.org/10.17509/jmee.v4i2.9627

Kustandi, C., \& Sutjipto, B. (2011). Media Pembelajaran: Manual dan digital (2nd ed.). Ghalia Indonesia.

Marpanaji, E., Wulandari, B., Mahali, M. I., \& Fajaryati, N. (2017). Trainer PID controller sebagai media pembelajaran praktik sistem kendali. Elinvo (Electronics, Informatics, and Vocational Education), 2(1), 27-40. https://doi.org/10.21831/elinvo.v2i1.16369

Narulita, R., Jaya, I., \& Taboer, M. A. (2021). Pengembangan media puzzle berseri untuk membantu meningkatkan kemampuan menggosok gigi pada anak autis kelas dasar. Jurnal Pendidikan Kebutuhan Khusus, 5(1), 24-35. https://doi.org/10.24036/jpkk.v5i1.565

Nizar, S. (2016). Pengembangan media pembelajaran trainer kit sensor dan aktuator untuk meningkatkan hasil belajar siswa kelas XI pada pelajaran teknik mikrokontroler di SMK YPT 1 Purbalingga [Universitas Negeri Yogyakarta]. http://eprints.uny.ac.id/46133/

Nuri, N., \& Rusilowati, A. (2018). Pembelajaran berbasis produksi sebagai upaya peningkatan keterampilan produktifitas siswa SMK. Physics Communication, 2(1), 46-51. https://doi.org/10.15294/physcomm.v2i1.11338

Pain, R. (1996). Practical electronic fault-finding and troubleshooting. Newnes. 
Rauner, F., \& Maclean, R. (2008). Handbook of technical and vocational education and training research. Springer. https://doi.org/10.1007/978-1-4020-8347-1

Rivai, A., \& Sudjana, N. (2011). Media pengajaran. Sinar Baru Algesindo.

Rizaldi, N. I. N., Putri, A. S., Calisa, T. R., \& Hikmawan, R. (2021). Apakah model pembelajaran problem-based learning efektif diterapkan pada pendidikan kejuruan abad 21? Integrated: Journal Of Information Technology and Vocational Education, 3(1), 23-31. https://ejournal.upi.edu/index.php/integrated/article/view/32735

Rustandi, A., Asyril, A., \& Hikma, N. (2020). Pengembangan media pembelajaran berbasis Android pada mata pelajaran simulasi dan komunikasi digital kelas X Sekolah Menengah Kejuruan Teknologi Informasi Airlangga tahun ajaran 2020/2021. Media Bina Ilmiah, 15(2), 40854092. https://doi.org/10.33758/mbi.v15i2.880

Sa'adah, L. (2021). Metode penelitian ekonomi dan bisnis (Z. Zulfikar (ed.)). Penerbit LPPM Universitas KH. A. Wahab Hasbullah.

Sani, R. A. (2016). Penilaian autentik. Bumi Aksara. http://digilib.unimed.ac.id/23839/1/Cover\%2C Kata Pengantar\%2C Daftar Isi.pdf

Setyo, M. (2016). Prinsip dan langkah-langkah penetapan KKM. Panduanmengajar.Blogspot.Com. https://panduanmengajar.blogspot.com/2016/01/prinsip-dan-langkah-langkahpenetapan.html

Setyosari, P. (2014). Menciptakan pembelajaran yang efektif dan berkualitas. JINOTEP (Jurnal Inovasi Dan Teknologi Pembelajaran) : Kajian Dan Riset Dalam Teknologi Pembelajaran, 1(1), 20-30. https://doi.org/10.17977/um031v1i12014p020

Sudira, P. (2013). Praksis pendidikan kejuruan Indonesia di antara mazab John Dewey dan Charles Prosser. Seminar Nasional Pendidikan Vokasi 2013, 197-206. http://eprints.uad.ac.id/2824/1/SNPV.pdf

Sugiyono, S. (2017). Metode penelitian dan pengembangan untuk bidang pendidikan, manajemen, sosial, teknik: Research and development $R \& D$. Alfabeta.

Sukir, S., Soenarto, S., \& Soeharto, S. (2017). Developing conveyor trainer kit for programmable logic controllers in practical learning. Jurnal Pendidikan Vokasi, 7(3), 329-339. https://doi.org/10.21831/jpv.v7i3.15352

Sukmadinata, N. S. (2008). Metode penelitian pendidikan. Remaja Rosdakarya.

Syech, R., Abdi, R., \& Tambunan, W. (2016). Penentuan konduktivitas listrik air Sungai Batang Lubuh dengan menggunakan metode jembatan Wheatstone. Jurnal APTEK, 8(2), 92-101. https://doi.org/10.30606/aptk.v8i2.855

Tafonao, T. (2018). Peranan media pembelajaran dalam meningkatkan minat belajar mahasiswa. Jurnal Komunikasi Pendidikan, 2(2), 103-114. https://doi.org/10.32585/jkp.v2i2.113

The United States Office of Personnel Management. (2013). All professional engineering positions, 0800. The United States Office of Personnel Management. https://www.opm.gov/policydata-oversight/classification-qualifications/general-schedule-qualificationstandards/0800/files/all-professional-engineering-positions-0800.pdf

Tooley, M., \& Tooley, M. H. (2002). Electronic circuits: Fundamentals and applications. Taylor \& Francis. https://books.google.co.id/books?id=CbFjeSBoKYUC

Wagner, T. (2008). The global achievement gap: Why even our best schools don't teach the new survival skills our children deed and what we can do about it. Basic Books.

Wahono, S. J., \& Sukir, S. (2020). Pengembangan trainer kit instalasi penerangan listrik dengan pelengkap sensor di SMK Negeri 1 Sedayu. Jurnal Edukasi Elektro, 4(2), 158-164. https://doi.org/10.21831/jee.v4i2.35829 
Wening, S. (2017). Revitalisasi pendidikan vokasi melalui inovasi sistem penilaian berbasis kecakapan abad ke-21. Prosiding Pendidikan Teknik Boga Busana FT UNY, 12(1). https://journal.uny.ac.id/index.php/ptbb/article/view/33341

Yayuk, S., \& Sugiyono, S. (2019). Pengaruh kepemimpinan kepala sekolah dan biaya pendidikan terhadap kualitas proses belajar mengajar dan dampaknya dengan kompetensi lulusan SMK di Kabupaten Gunungkidul. Jurnal Akuntabilitas Manajemen Pendidikan, 7(1), 84-96. https://doi.org/10.21831/amp.v7i1.23758 